\title{
Synthesis of the Prospective Anticancer Molecule Perillic Acid from Orange Essential Oil by the Yeast Yarrowia lipolytica
}

\author{
Marcelo R. R. Tappin', Felipe M. Knopp², Igor C. Cardoso'1, Roberta T. Santos ${ }^{1}$, \\ Bruna S. Drummond1, Antonio C. Siani1 ${ }^{1}$, Elba P. S. Bon ${ }^{2}$, Maria Antonieta Ferrara ${ }^{*}$ \\ ${ }^{1}$ Institute of Drug Technology, Oswaldo Cruz Foundation, Rio de Janeiro, Brazil \\ ${ }^{2}$ Chemistry Institute, Federal University of Rio de Janeiro, Rio de Janeiro, Brazil \\ Email: *ferrara@far.fiocruz.br
}

How to cite this paper: Tappin, M.R.R., Knopp, F.M., Cardoso, I.C., Santos, R.T., Drummond, B.S., Siani, A.C., Bon, E.P.S. and Ferrara, M.A. (2017) Synthesis of the Prospective Anticancer Molecule Perillic Acid from Orange Essential Oil by the Yeast Yarrowia lipolytica. Green and Sustainable Chemistry, 7, 172-184.

https://doi.org/10.4236/gsc.2017.72013

Received: April 26, 2017

Accepted: May 22, 2017

Published: May 25, 2017

Copyright $\odot 2017$ by authors and Scientific Research Publishing Inc. This work is licensed under the Creative Commons Attribution International License (CC BY 4.0).

http://creativecommons.org/licenses/by/4.0/

\section{(c) (i) Open Access}

\begin{abstract}
The bioconversion of the hydrophobic and volatile limonene to perillic acid, a potential anticancer agent, by the yeast Yarrowia lipolytica was studied in two steps. Firstly, experimental design was used for process optimization using high-purity limonene as substrate and secondly orange essential oil containing 89.1\% limonene was used as substrate under the previously optimized conditions. Limonene concentration and $\mathrm{pH}$ were identified by fractional factorial design as significant factors and were optimized by central composite design. Under optimized process conditions ( $0.16 \%$ (v/v) limonene; $\mathrm{pH} 6.9)$, the $24 \mathrm{~h}$ biotransformation process resulted in the accumulation of $0.368 \mathrm{~g} \cdot \mathrm{L}^{-1}$ of perillic acid corresponding to a molar yield of $23.1 \%$. A subsequent substrate addition under the same reaction conditions doubled perillic acid concentration to $0.793 \mathrm{~g} \cdot \mathrm{L}^{-1}$ and a molar yield of $24.2 \%$. The use of orange essential oil under the optimized reaction conditions increased both perillic acid accumulation and yield to $0.872 \mathrm{~g} \cdot \mathrm{L}^{-1}$ and $29.7 \%$, respectively. The robustness of $Y$. lipolytica allowed the efficient biotransformation of a crude by-product of the citrus industry into a valuable fine chemical.
\end{abstract}

\section{Keywords}

Yarrowia lipolytica, Bioconversion, Perillic Acid, Limonene, Orange Essential Oil

\section{Introduction}

The compounds perillyl alcohol, perillaldehyde and perillic acid, derived from the limonene molecule through the oxidation of its exocyclic methyl group, are 
known for presenting several biological activities. Perillaldehyde presents antimicrobial property [1] and perillyl alcohol is currently on clinical trials as a multi-target anti-cancer agent [2] [3]. The prospective anticancer activity of perillic acid relates to the accepted mechanism for these monoterpenes as inhibitors of protein prenylation in cancer cells [4] as well as its presence in human plasma after limonene [5] or perillyl alcohol [6] administration. Indeed, perillic acid has demonstrated to be effective in a range of antitumor in vitro assays [7] [8] [9] [10].

With rare exceptions [11] volatile monoterpenes in plants present low perillic derivatives content since the $\mathrm{O}_{2} / \mathrm{NADPH}$-dependent biosynthetic step to hydroxylate the limonene moiety in plant cells is known to produce complex mixtures of perillyl, carvyl and menthyl alcohols [12]. Furthermore, perillic derivatives are difficult to obtain by chemical oxidation of limonene, given that the insertion of oxygen into the terminal methyl group is less favourable in comparison to other sites of the molecule. In fact, the allylic hydroxylation of limonene catalyzed by either palladium compounds [13] or metal silicates [14] is highly favored to take place in the cyclic carbons rather than the terminal methyl group of limonene molecule, to generate menthol and carveol isomers.

Nevertheless, several studies on the microbial or enzymatic bio-oxidation of limonene have shown effectiveness to oxyfunctionalize exclusively the exocyclic methyl group for the production of perillic acid [15] [16]. Biotransformation processes using wild type or genetically modified Pseudomonas putida cells have shown to be quite promising for the production of perillic acid as a molecule of industrial interest for natural preservation and pharmaceutical application [17] [18] [19]. Studies on this theme included the use of a tubular segmented-flow biofilm reactor in a multistep process with high productivity [19]. Investigations have also been carried out with the bacteria Escherichia and Mycobacterium [16]. The fungus Aspergillus cellulosae [16] and the non-conventional yeasts Arxula adeninivorans and Yarrowia lipolytica [20] have also been approached to converting limonene to perillic derivatives. Recently, our research group successfully studied the bio-oxidation of $R$-(+)-limonene into $R-(+)$-perillic acid by $Y$. lipolytica ATCC 18942 [21], which is recognized as safe and suitable yeast to be used in processes aiming at products for human consumption [22] [23]. As a continuation of the previous study, the present work aimed to increase the perillic acid yield from high-purity limonene, by applying statistical design of experiments to the bioreaction parameters. Finally, the optimized biotransformation conditions were applied to a crude orange essential oil sample representing an industrial terpenoid mixture containing $83 \%$ to $97 \%$ of $R$-(+)-limonene.

\section{Materials and Methods}

\subsection{Microorganism, Media, Yeast Cultivation and Bioconversion Assays}

Y. lipolytica ATCC 18942 was obtained from the National Institute for Quality

Control in Health, Oswaldo Cruz Foundation collection (INCQS 40149, Fiocruz, 
Rio de Janeiro, Brazil). Cells were grown in Yeast Malt Broth medium (glucose $10 \mathrm{~g} \cdot \mathrm{L}^{-1}$, yeast extract $3 \mathrm{~g} \cdot \mathrm{L}^{-1}$, malt extract $3 \mathrm{~g} \cdot \mathrm{L}^{-1}$ and peptone $5 \mathrm{~g} \cdot \mathrm{L}^{-1}$ ) at $28^{\circ} \mathrm{C}$ under stirring $(200 \mathrm{rpm})$ during $48 \mathrm{~h}$. For the bioconversion experiments, cells were separated by centrifugation $(3000 \times g)$ and re-suspended in phosphate buffer $(50 \mathrm{mM})$ at $20 \mathrm{~g} \cdot \mathrm{L}^{-1} \cdot R$-(+)-limonene $97 \%$ (Sigma) was added and the mixture was incubated under stirring at $200 \mathrm{rpm}$. Temperature, $\mathrm{pH}$, nutrient addition and limonene concentration were the factors selected for experimental design and their values varied through the experiments.

\subsection{Experimental Design}

A fractional factorial design [24] was carried out for screening significant factors for limonene bioconversion to perillic acid. Process temperature, process $\mathrm{pH}$, initial $R$-(+)-limonene concentration and nutrient addition were selected at the levels shown in Table 1. The experiments were performed in duplicate and perillic acid concentration, measured at $24 \mathrm{~h}$ and $48 \mathrm{~h}$, was the response variable.

For the bioconversion optimization, a central composite design [24] was carried out having initial $R-(+)$-limonene concentration and $\mathrm{pH}$ as variables at the levels shown in Table 2. Nutrients were not added and the temperature was kept at $25^{\circ} \mathrm{C}$. Experiments were performed in non-simultaneous triplicate and aliquots of the bioconversion medium were collected at 24 and $48 \mathrm{~h}$ for perillic acid quantification. Two responses (dependent variables) were considered for the statistical analysis: perillic acid concentration and molar bioconversion yield (which considers perillic acid production related to the initial limonene concentration). For each response at each time ( $24 \mathrm{~h}$ and $48 \mathrm{~h}$ ), the prediction model was calculated such as:

$$
\hat{y}=b_{0}+b_{\text {Lim }} x_{\text {Lim }}+b_{p H} x_{p H}+b_{\text {LimpH }} x_{\text {Lim }} x_{p H}+b_{\text {Lim }}^{2} x_{\text {Lim }}^{2}+b_{p H}^{2} x_{p H}^{2}
$$

Table 1. Trial of variables by fractional factorial design: cell mass fixed at $20 \mathrm{~g} \cdot \mathrm{L}^{-1}$.

\begin{tabular}{ccccc}
\hline \multicolumn{5}{c}{ Variables and levels } \\
\hline Run & $\mathrm{T}\left({ }^{\circ} \mathrm{C}\right)$ & $\mathrm{pH}$ & Initial Limonene concentration $(\% \mathrm{v} / \mathrm{v})$ & Nutrients $^{*}(\% \mathrm{v} / \mathrm{v})$ \\
\hline 1 & $-(20.0)$ & $-(6.2)$ & $-(0.1)$ & $-(0)$ \\
2 & $-(20.0)$ & $-(6.2)$ & $+(0.5)$ & $+(10)$ \\
3 & $-(20.0)$ & $+(7.2)$ & $-(0.1)$ & $+(10)$ \\
4 & $-(20.0)$ & $+(7.2)$ & $+(0.5)$ & $-(0)$ \\
5 & $+(25.0)$ & $-(6.2)$ & $-(0.1)$ & $+(10)$ \\
6 & $+(25.0)$ & $-(6.2)$ & $+(0.5)$ & $-(0)$ \\
7 & $+(25.0)$ & $+(7.2)$ & $-(0.1)$ & $+(0)$ \\
8 & $+(25.0)$ & $+(7.2)$ & $+(0.5)$ & $0(5)$ \\
9 & $0(22.5)$ & $0(6.7)$ & $0(0.3)$ & $0(5)$ \\
10 & $0(22.5)$ & $0(6.7)$ & $0(0.3)$ & $0(5)$ \\
11 & $0(22.5)$ & $0(6.7)$ & $0(0.3)$ & \\
\hline
\end{tabular}

${ }^{*}$ Nutrients solution: $3 \mathrm{~g} \cdot \mathrm{L}^{-1}$ yeast extract, $3 \mathrm{~g} \cdot \mathrm{L}^{-1}$ malt extract, $5 \mathrm{~g} \cdot \mathrm{L}^{-1}$ peptone, $10 \mathrm{~g} \cdot \mathrm{L}^{-1}$ glucose. 
Table 2. Optimization by central composite design. Cell mass was fixed at $20 \mathrm{~g} \cdot \mathrm{L}^{-1}$ and temperature at $25^{\circ} \mathrm{C}$.

\begin{tabular}{ccc}
\hline & \multicolumn{3}{c}{ Variables and levels } \\
\hline Run & Limonene $(\% \mathrm{v} / \mathrm{v})$ & $\mathrm{pH}$ \\
\hline 1 & $-(0.16)$ & $-(6.35)$ \\
2 & $-(0.16)$ & $+(7.05)$ \\
3 & $+(0.44)$ & $-(6.35)$ \\
4 & $+(0.44)$ & $+(7.05)$ \\
5 & $\mathrm{a}(0.10)$ & $0(6.7)$ \\
6 & $\mathrm{~A}(0.50)$ & $0(6.7)$ \\
7 & $0(0.30)$ & $\mathrm{a}(6.2)$ \\
8 & $0(0.30)$ & $\mathrm{A}(7.2)$ \\
9 & $0(0.30)$ & $0(6.7)$ \\
10 & $0(0.30)$ & $0(6.7)$ \\
11 & $0(0.30)$ & $0(6.7)$ \\
\hline
\end{tabular}

where $\hat{y}$ is the predicted response, $b_{0}$ is the intercept, $b_{\text {Lim }}$ is the linear coefficient of the limonene concentration, $x_{L i m}$ is the codified value of the limonene concentration, $b_{p H}$ is the linear coefficient of the $\mathrm{pH}, x_{p H}$ is the codified value of the $\mathrm{pH}$, $b_{\text {LimpH }}$ is the coefficient for the interaction between limonene concentration and $\mathrm{pH}, \quad b_{\text {Lim }}^{2}$ is the quadratic coefficient of the limonene concentration, $b_{p H}^{2}$ is the quadratic coefficient of $\mathrm{pH}$ value. Design settings and calculations were performed in JMP Statistical Discovery Software version 8.

\subsection{Stepwise Addition of Limonene}

The conditions optimized by central composite design, $\mathrm{pH} 6.9$ and $R-(+)$-limonene concentration of $0.16 \%(\mathrm{v} / \mathrm{v})$ were applied in a bioconversion experiment where a fresh equal $R-(+)$-limonene dose was added after $24 \mathrm{~h}$. Aliquots were collected at $24 \mathrm{~h}$ and $48 \mathrm{~h}$ for perillic acid concentration measurement. Experiment was performed in duplicate.

\subsection{Use of Orange Essential Oil for the Production of Perillic Acid}

The high-purity limonene optimized process conditions were applied to the bioconversion of the orange essential oil (from Tropfruit Nordeste S. A, Estância, Brazil). This substrate was added to the yeast medium in two portions $(2 \times 0.16 \% \mathrm{v} / \mathrm{v}, \mathrm{pH} 6.9)$ at the beginning and after $24 \mathrm{~h}$ of bioconversion. Overall yield was taken after $48 \mathrm{~h}$ reaction.

\subsection{Analytical Procedures}

Cell mass concentration was determined by optical density at $600 \mathrm{~nm}\left(\mathrm{OD}_{600}\right)$. One $\mathrm{OD}_{600}$ unit corresponded to a dry cell concentration of $0.444 \mathrm{~g} \cdot \mathrm{L}^{-1}$. Glucose concentration was measured using an YSI 2700 Select Biochemistry Analyzer 
(Yellow Springs). Perillic acid was determined by gas chromatography (GC) using (S)-(-)-perillic acid 95\% from Sigma-Aldrich as standard. A sample of the bioconversion supernatant was cleared of debris by centrifuging $15 \mathrm{~min}$ at 15000 $\times g$ and a $1.00 \mathrm{~mL}$ supernatant aliquot was transferred to a $1.7 \mathrm{~mL}$ microcentrifuge tube (tube 1). Perillic acid was precipitated by adding $100 \mu \mathrm{l}$ of $\mathrm{HCl} 0.6 \mathrm{M}$ solution and the resulting suspension was homogenized and centrifuged at $15000 \times g$ during 15 minutes. The supernatant was transferred to another $1.7 \mathrm{~mL}$ microcentrifuge tube and after repeating the precipitation procedure, the supernatant was discarded. The precipitates from both tubes were dissolved with ethyl acetate and transferred to a $2.00 \mathrm{~mL}$ volumetric flask that was filled up with the same solvent. After homogenization the perillic acid solution was analyzed using a GC instrument from Agilent Technologies model 7890 equipped with a 7683 injector and autosampler, split/splitless injector and flame ionization detector (Santa Clara, USA). A J \& W Scientific HP-Innowax column with a bonded polyethylene glycol phase, $30 \mathrm{~m}$ length, $250 \mu \mathrm{m}$ internal diameter and $0.250 \mu \mathrm{m}$ film thickness, was used. All analyses were performed using a temperature program, constant flow, and split injection. The chromatographic conditions were as follows: oven temperature initiated at $50^{\circ} \mathrm{C}$, temperature increasing to $250^{\circ} \mathrm{C}$ at $20^{\circ} \mathrm{C} \mathrm{m^{-1 }}$, held for $5 \mathrm{~min}$; the run time was $15 \mathrm{~min}$. The injector temperature was set at $280^{\circ} \mathrm{C}$, and detector temperature set at $300^{\circ} \mathrm{C}$. Helium was the carrier gas at a flow rate of $1 \mathrm{~mL} \cdot \mathrm{min}^{-1}$. Injection volume was $1.0 \mu \mathrm{l}$ with the split ratio set at 25:1.

Limonene content in the crude orange essential oil was determined by GC using $R$-(+)-limonene 97\% from Sigma as standard. GC-column was a DB-5 30 $\mathrm{m}$ length, $250 \mu \mathrm{m}$ internal diameter and $0.250 \mu \mathrm{m}$ film thickness. The chromatographic conditions were as follows: the oven temperature was kept at $70^{\circ} \mathrm{C}$ for $5 \mathrm{~min}$ and then increased at $4^{\circ} \mathrm{C} \mathrm{min}^{-1}$ up to $170^{\circ} \mathrm{C}$; the run time was $30 \mathrm{~min}$. The injector was set at $250^{\circ} \mathrm{C}$ and the detector at $300^{\circ} \mathrm{C}$. Helium was the carrier gas at a flow rate of $0.5 \mathrm{~mL} \cdot \mathrm{min}^{-1}$. Injection volume was $1.0 \mu \mathrm{l}$ with the split ratio set at 50:1.

\section{Results}

\subsection{Screening of Variables Using Experimental Design}

Previous results from our laboratory showed the yeast cell mass and limonene concentrations, $\mathrm{pH}$, temperature and nutrient addition as relevant variables to be assessed for limonene bioconversion to perillic acid, as well as their range values [21]. Cell mass concentration, assayed to sub-levels 5.0 - $12.5-20.0 \mathrm{~g} \cdot \mathrm{L}^{-1}$ in a preliminary fractional factorial design experiment, showed a preponderant influence on the response, impairing the assessment of the remaining variables (data not shown). Hence, the screening was designed by fixing the cell mass concentration at $20 \mathrm{~g} \cdot \mathrm{L}^{-1}$ and varying the other factors as shown in Table 1.

The statistical analysis (Figure 1) showed that the most relevant factors were the limonene concentration followed by the $\mathrm{pH}$. In the range assayed, the temperature was of low significance at $24 \mathrm{~h}$ and non-significant at $48 \mathrm{~h}$. Therefore, 


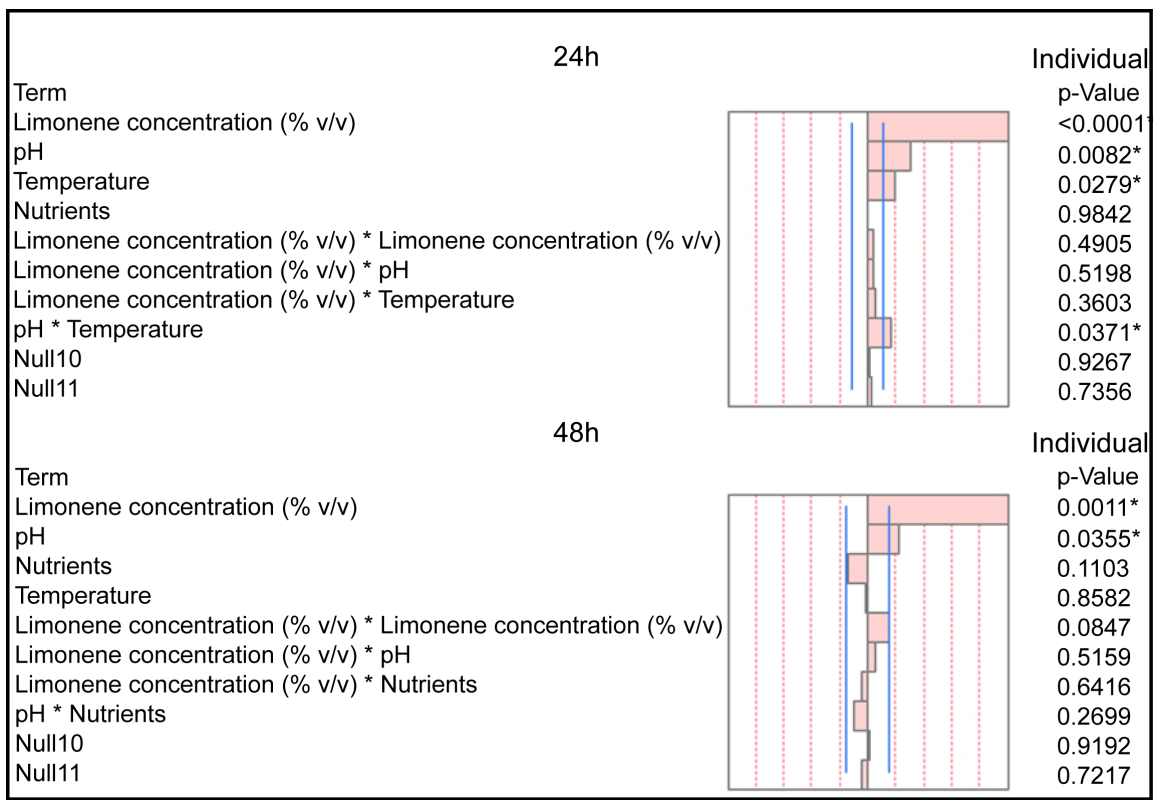

Figure 1. Significance chart for the assessed factors in the fractional factorial design for the bioconversion of limonene to perillic acid.

for the subsequent experiments, the temperature was fixed at $25^{\circ} \mathrm{C}$. The addition of a nutrient solution (containing macro-micronutrients, and growth factors that would be required for cell maintenance and/or enzymatic activity) was not significant for the perillic acid production, even though glucose, when present, was fully metabolized (data not shown). This result indicated that the bioconversion could be carried out without appending extra nutrients to the medium.

\subsection{Optimization Using Response Surface Methodology}

Process optimization with the two selected variables, limonene concentration and $\mathrm{pH}$, was performed by central composite design according to Table 2. Figure 2 shows the effects of the factors on perillic acid concentration and on the bioconversion molar yield at $24 \mathrm{~h}$ and $48 \mathrm{~h}$. The linear and the quadratic effects of limonene concentration were significant for perillic acid concentration at both time intervals. When considering the yield as the response variable, the linear effect of limonene concentration was significant at $24 \mathrm{~h}$ while the quadratic effect was significant at $48 \mathrm{~h}$. PH effects in the range assayed were not significant for both responses in this experiment. Predictive models were generated for each response (product concentration and molar bioconversion yield) as shown in Table 3. The profiles displayed in Figure 3 and Figure 4 showed that the optimum conditions were different according to the type of response evaluated thereof. The overall maximum predicted perillic acid concentration $(0.868 \pm 0.076$ $\left.\mathrm{g} \cdot \mathrm{L}^{-1}\right)$ was reached with $0.44 \%(\mathrm{v} / \mathrm{v})$ initial limonene concentration and $\mathrm{pH} 6.94$ at $48 \mathrm{~h}$ (Figure $4(\mathrm{a})$ ). Nevertheless, this value was only $23 \%$ higher than the maximum predicted at $24 \mathrm{~h}\left(0.706 \pm 0.062 \mathrm{~g} \cdot \mathrm{L}^{-1}\right)$ for $0.40 \%(\mathrm{v} / \mathrm{v})$ limonene concentration and $\mathrm{pH} 6.96$ (Figure 3(a)). The predicted bioconversion yields for these conditions were $20.4 \% \pm 2.6 \%$ and $18.4 \% \pm 2.2 \%$, respectively. On the other 


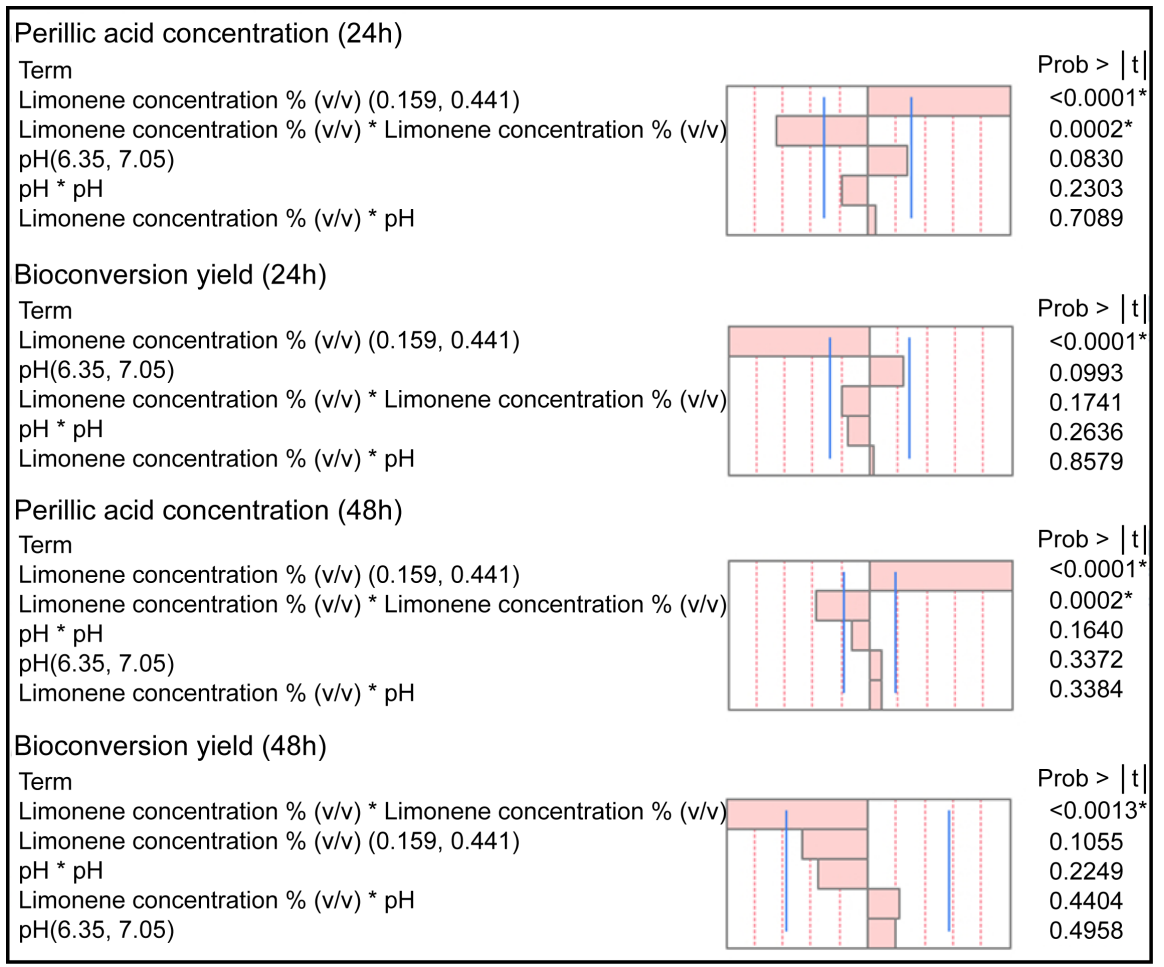

Figure 2. Effects graph for the assessed factors in the central composite design.

Table 3. Prediction models for each response.

\begin{tabular}{|c|c|}
\hline Response & Prediction model \\
\hline Perillic acid concentration $\left(\mathrm{g} \cdot \mathrm{L}^{-1}\right) 24 \mathrm{~h}$ & $\begin{array}{l}\hat{y}=0.64891438888889+0.12883473167398 x_{L i m} \\
+0.03545373207567 x_{p H}+0.01050779166667 x_{L i m} X_{p H} \\
-0.0995462777778 x_{\text {Lim }}^{2}-0.0287720694444 x_{p H}^{2}\end{array}$ \\
\hline Bioconversion yield (\%) $24 \mathrm{~h}$ & $\begin{array}{l}\hat{y}=21.0544323390805-4.7538065958408 x_{\text {Lim }} \\
+1.11120440122768 x_{p H}+0.16644282070712 x_{\text {Lim }} X_{p H} \\
-1.0815310302604 x_{\text {Lim }}^{2}-0.8475487296127 x_{p H}^{2}\end{array}$ \\
\hline Perillic acid concentration $\left(\mathrm{g} \cdot \mathrm{L}^{-1}\right) 48 \mathrm{~h}$ & $\begin{array}{l}\hat{y}=0.72121044444444+0.23301431549124 x_{L i m} \\
+0.019971336804 x_{p H}+0.02817066666667 x_{L i m} X_{p H} \\
-0.1028183680556 x_{\text {Lim }}^{2}-0.0348015347222 x_{p H}^{2}\end{array}$ \\
\hline Bioconversion yield (\%) $48 \mathrm{~h}$ & $\begin{array}{l}\hat{y}=23.4001229820067-1.1416892754269 x_{\text {Lim }} \\
+0.47061378146558 x_{p H}+0.75476044841651 x_{L i m} X_{p H} \\
-2.9209782138728 x_{L i m}^{2}-1.0075914617546 x_{p H}^{2}\end{array}$ \\
\hline
\end{tabular}

hand, the maximum predicted bioconversion yields were $25.7 \% \pm 2.4 \%(0.428 \pm$ $0.069 \mathrm{~g} \cdot \mathrm{L}^{-1}$ perillic acid) at $24 \mathrm{~h}$ (Figure $\left.3(\mathrm{~b})\right)$ and $24.3 \% \pm 2.3 \%(0.681 \pm 0.067$ $\mathrm{g} \cdot \mathrm{L}^{-1}$ perillic acid) at $48 \mathrm{~h}$ (Figure $\left.4(\mathrm{~b})\right)$ at much lower limonene concentrations, $0.16 \%$ ( $\mathrm{pH} 6.9$ ) and $0.28 \%(\mathrm{pH} 6.76$ ), respectively. The fact that the higher limonene concentrations resulted in lower bioconversion yields could be assigned to the limonene toxicity towards the yeast cells as well as to its volatility. These effects had already been described during previous limonene bio-oxidation studies 


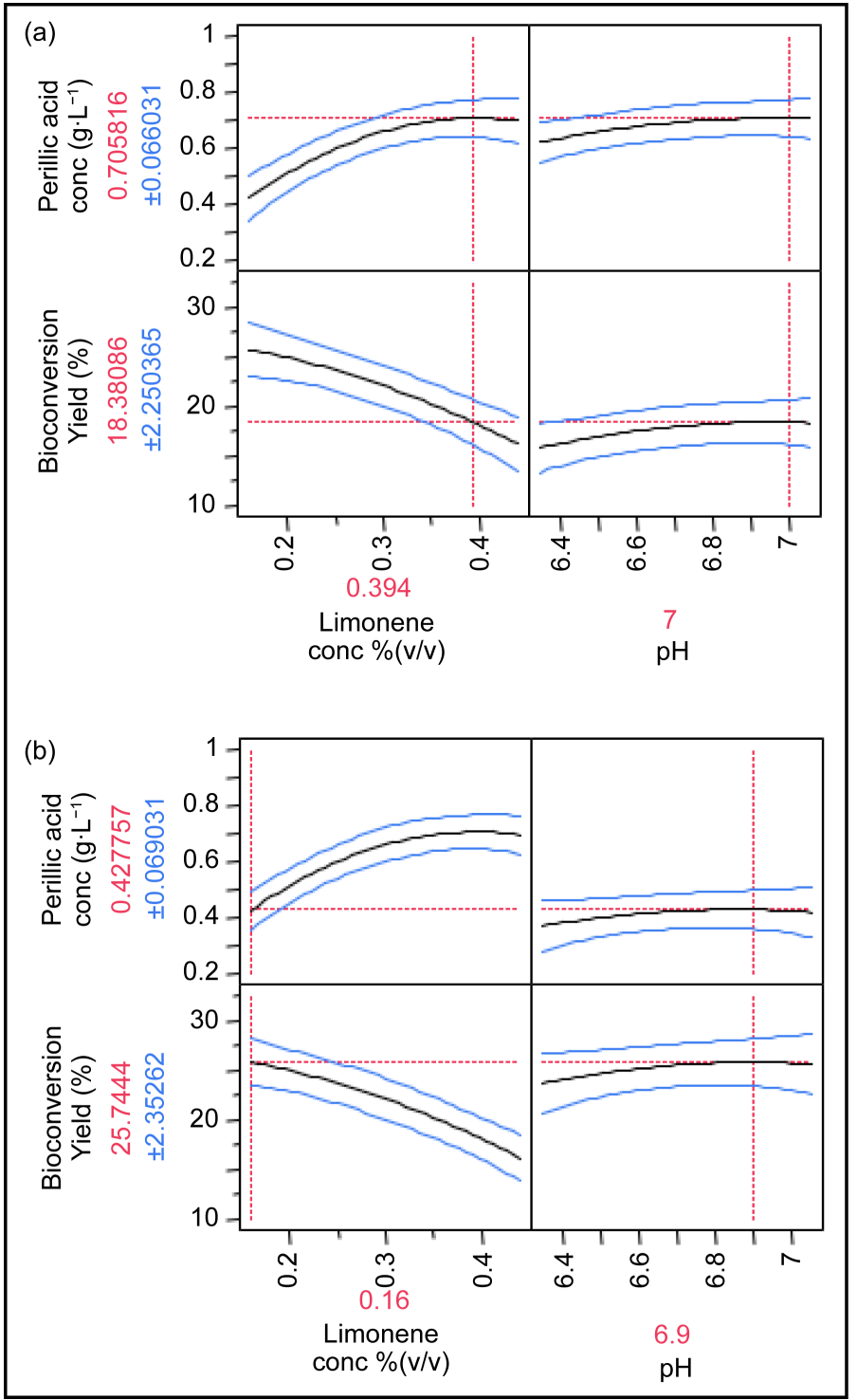

Figure 3. Profiles of the measured responses at $24 \mathrm{~h}$ : (a) optimum conditions for perillic acid concentration; (b) optimum conditions for bioconversion yield.

[21]. The $\mathrm{pH}$ was not significant for the measured responses at 24 and $48 \mathrm{~h}$. Nevertheless, this parameter was included in the predictive model.

\subsection{Stepwise Addition of Limonene}

The statistical modeling indicated that the use of $0.16 \%$ limonene allowed the maximum molar yield within $24 \mathrm{~h}$ bioconversion suggesting that this initial limonene concentration coupled to a fresh limonene addition after $24 \mathrm{~h}$ might increase perillic acid concentration while keeping the bioconversion yield. To assess this possibility, a new test was conducted using $0.16 \%$ limonene at $\mathrm{pH} 6.9$ followed by an equal limonene addition after $24 \mathrm{~h}$. The product concentration reached $0.368 \mathrm{~g} \cdot \mathrm{L}^{-1}$ perillic acid (23.1\% yield) after $24 \mathrm{~h}$, within the model prediction interval between $0.358 \mathrm{~g} \cdot \mathrm{L}^{-1}$ and $0.496 \mathrm{~g} \cdot \mathrm{L}^{-1}$. After the second limonene 


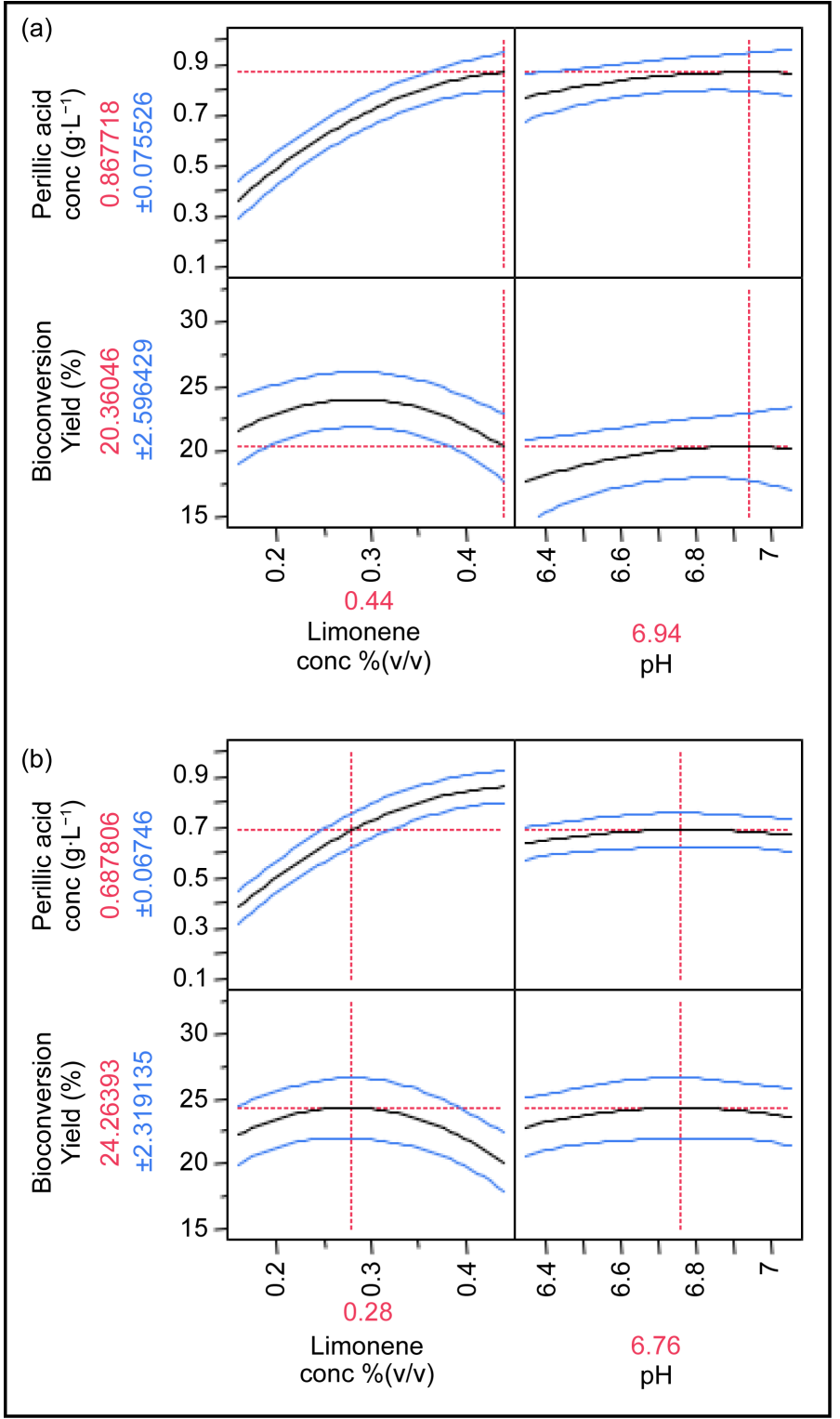

Figure 4. Profiles of the measured responses at $48 \mathrm{~h}$ : (a) optimum conditions for perillic acid concentration; (b) optimum conditions for bioconversion yield.

addition, the bioconversion process resumed reaching $0.793 \mathrm{~g} \cdot \mathrm{L}^{-1}$ of perillic acid (24.2\% yield) within $48 \mathrm{~h}$ of the total bioconversion process. The two steps limonene addition resulted advantageous either comparing with the intermittent six-portions limonene feeding used in the previous study $(0.5 \%$ total over $48 \mathrm{~h}$; perillic acid concentration increasing by $50 \%$ ) or to the total single limonene addition at the beginning of the experiment. Furthermore, the present study improved the reaction molar yield by 1.5 fold in comparison to the previous maximum yield of $16.7 \%$ [21].

\subsection{Bioconvertion of Orange Essential Oil into Perillic Acid}

The optimized conditions found to the bioconversion of high-purity limonene 
with Yarrowia lipolytica were replicated by using orange essential oil containing $89.1 \%$ limonene. Within $48 \mathrm{~h}$ bioconversion, an accumulation of $0.872 \mathrm{~g} \cdot \mathrm{L}^{-1}$ of perillic acid (29.7\% molar yield) was achieved; these values being higher than the observed for the use of high-purity limonene. The yield increase could be due to better substrate dispersion, as visually observed. In fact, crude orange oil presents a large variety of components such as oxidized derivatives of other monoterpenes and sesquiterpenes (data not shown) [25] that, nevertheless in minor amounts, would increase the availability of the limonene molecule to the yeast cells.

\section{Discussion}

Table 4 compares published data from our laboratory [21] and data from the present work regarding the main biotransformation process parameters in terms of reaction conditions, perillic acid final concentration and perillic acid molar yield. The handling of volatile limonene to enhance its bioavailability to the yeast cells in a stirred-process of bioconversion, without using emulsifiers, turned out to be quite challenging. Thus, six limonene additions to the reaction medium had been done over a period of $48 \mathrm{~h}$ in our previous work [21]. In the present study however, only two additions were needed, which meant an operational gain, without decreasing the final product concentration. Although the product concentrations obtained by the three reaction conditions presented in Table 4 were very similar, with an average value of $0.85 \mathrm{~g} \cdot \mathrm{L}^{-1}$, the molar yields increased $50 \%$ and $78 \%$ in the optimized process by using high-purity limonene or the orange oil as substrate, respectively. The use of lower substrate amounts of $35 \%$ for high-purity limonene and $41 \%$ for crude orange oil represented a significant feedstock saving, an important issue regarding cost and process sustainability.

Table 4 also compares the cost of the high-purity limonene or orange oil substrates, for the production of $1 \mathrm{Kg}$ of perillic acid. The biotransformation process using orange oil resulted in an important decrease in the cost from either 552.38

Table 4. Comparison of the main biotransformation process parameters, production data of perillic acid (PA) by Yarrowia lipolytica and substrate cost for the use of high-purity limonene (published data and present study) and orange oil (data from the present study).

\begin{tabular}{|c|c|c|c|}
\hline \multirow{2}{*}{ Measured parameter } & \multirow{2}{*}{$\begin{array}{c}\text { Previous process }{ }^{1} \\
\text { Limonene ( } 96 \% \text { purity) }\end{array}$} & \multicolumn{2}{|c|}{ Optimized process ${ }^{2}$} \\
\hline & & Limonene (97\% purity) & Orange oil (89\% limonene) \\
\hline Bioconversion conditions & $25^{\circ} \mathrm{C} ; \mathrm{pH} 7.1 ; 10 \mathrm{~g} \cdot \mathrm{L}$ cell mass (dry weight) & \multicolumn{2}{|c|}{$25^{\circ} \mathrm{C} ; \mathrm{pH} 6.9 ; 20 \mathrm{~g} / \mathrm{L}$ cell mass (dry weight) } \\
\hline Total limonene amount $(\mathrm{mM})^{3}$ & $29.7\left(4.0 \mathrm{~g} \cdot \mathrm{L}^{-1}\right)$ & $19.2\left(2.6 \mathrm{~g} \cdot \mathrm{L}^{-1}\right)$ & $17.6\left(2.4 \mathrm{~g} \cdot \mathrm{L}^{-1}\right)$ \\
\hline Limonene addition mode over $48 \mathrm{~h}$ & 6 additions & 2 additions & 2 additions \\
\hline Final PA concentration & $0.855 \mathrm{~g} \cdot \mathrm{L}^{-1}$ & $0.796 \mathrm{~g} \cdot \mathrm{L}^{-1}$ & 0.872 g. $\mathrm{L}^{-1}$ \\
\hline PA molar yield & $16.7 \%$ & $25,0 \%$ & $29.7 \%$ \\
\hline $\begin{array}{l}\text { Cost of limonene substrate to } \\
\text { produce } 1 \mathrm{Kg} \mathrm{PA}\end{array}$ & $552.38 \mathrm{USD}^{4}$ & $386.67 \mathrm{USD}^{4}$ & $\begin{array}{l}80.56 \mathrm{USD}^{4} \\
12.90 \mathrm{USD}^{5}\end{array}$ \\
\hline
\end{tabular}

${ }^{1}$ See ref. [21]. ${ }^{2}$ Optimized conditions using experimental design (this work). ${ }^{3}$ Calculated considering the substrate purity degree. ${ }^{4}$ Estimated from prices of $(R)-(+)$-limonene and orange oil from Sigma-Aldrich. ${ }^{5}$ Estimated from price of orange oil from the Brazilian Company Tropfruit Nordeste S. A. 
USD (non-optimized process) or 386.67 USD (optimized process) for high-purity limonene to 80.56 USD or 12.90 USD for imported or Brazil produced orange oil.

These results are quite valuable due to the present industrial scenario where low-cost industrial feedstocks are particularly at aim for supplying the fine chemical-based industries [26]. Orange essential oil is largely available due to a worldwide orange production of 70 million tons per year [27]. The orange-based industry ( 28 million tons/year) by itself generates residues amounting $50 \%$ of the raw processed fruit whereby the orange oil represents approximately $5 \%$ (on dry basis) [28] and can be obtained directly from the cold pressing citrus zests. In this scenario, the large availability of orange essential oil coupled to an environmentally friendly yeast based process to produce perillic acid could be extensively explored to establish a cost-effective synthesis of pharmaceutically valuable molecules. It is also relevant to stress the particular characteristics of $Y$. lipolytica as a robust yeast able to assimilate a great diversity of substrates, being tolerant to pollutants [22] [23] and thus very attractive to industrial use. Besides, the easiness of yeast separation from the biotransformation reaction mixture, as compared to bacteria, is another advantage for the process scale up.

\section{Conclusion}

The use of statistical design of experiments allowed determining how each reaction condition influenced the selective bio-oxidation of the limonene molecule in order to maximize the formation of perillic acid using a minimum amount of substrate. This approach resulted in $24.2 \%$ bioconversion yield on limonene basis, representing an increase of 1.5 fold, as compared to previous reported results. The aforementioned process conditions were applied to orange essential oil, increasing the molar yield even further to $29.7 \%$ corresponding to $0.872 \mathrm{~g} \cdot \mathrm{L}^{-1}$ of perillic acid, showing the robustness of $Y$. lipolytica towards this new substrate. The process feasibility using a highly-available industrial feedstock to produce a valuable fine chemical is promising due to the well-known advantages embodied by a green chemistry process as well as to the strategic and cost advantages conveyed by the use of a citrus industry by-product.

\section{Acknowledgements}

This research was supported by Fundação de Amparo à Pesquisa do Estado do Rio de Janeiro (FAPERJ), Grant E-26/110.856/2013.

\section{References}

[1] Kang, R., Heims, R., Stout, M.J., Jaber, H., Chen, Z. and Nakatsu, T. (1992) Antimicrobial Activity of the Volatile Constituents of Perilla frutescens and Its Synergistic Effect with Polygodial. Journal of Agricultural and Food Chemistry, 40, 2328-2330. https://doi.org/10.1021/jf00023a054

[2] Da Silveira, F.C.A., Lopes, B.A., Fonseca, C.O., Quirico-Santos, T., Paixão, I.C.N.P. and Amorim, L.M.F. (2012) Analysis of EGF $+61 \mathrm{~A}>\mathrm{G}$ polymorphism and EGF 
Serum Levels in Brazilian Glioma Patients Treated with Perillyl Alcohol-Based Therapy. Journal of Cancer Research and Clinical Oncology, 138, 1347-1354. https://doi.org/10.1007/s00432-012-1203-5

[3] Silva, M.M., Da Fonseca, C.O., Moura-Neto, R., Carvalho, J.F., Quirico-Santos, T. and Carvalho, M.G. (2013) Influence of GSTM1 and GSTT1 Polymorphisms on the Survival Rate of Patients with Malignant Glioma under Perillyl Alcohol-Based Therapy. Genetics and Molecular Research, 12, 1621-1630.

https://doi.org/10.4238/2013.May.14.2

[4] Gelb, M.H., Tamanoi, F., Yokoyama, K., Ghomashchi, F., Esson, K. and Gould, M. N. (1995) The Inhibition of Protein Prenyltransferases by Oxygenated Metabolites of Limonene and Perillyl Alcohol. Cancer Letters, 91, 169-175.

https://doi.org/10.1016/0304-3835(95)03747-K

[5] Chow, H.S., Salazar, D. and Hakim, I.A. (2002) Pharmacokinetics of Perillic Acid in Humans after a Single Dose Administration of a Citrus Preparation Rich in D-Limonene Content. Cancer Epidemiology and Prevention Biomarkers, 11, 1472-1476.

[6] Yeruva, L., Pierre, K.J., Elegbede, A., Wang, R.C. and Carper, S.W. (2007) Perillyl Alcohol and Perillic Acid Induced Cell Cycle and Apoptosis in Non-Small Cell Lung Cancer. Cancer Letters, 257, 216-226. https://doi.org/10.1016/j.canlet.2007.07.020

[7] Bardona, S., Foussardb, V., Fournelb, S. and Loubat, A. (2002) Monoterpenes Inhibit Proliferation of Human Colon Cancer Cells by Modulating Cell Cycle-Related Protein Expression. Cancer Letters, 181, 187-194. https://doi.org/10.1016/S0304-3835(02)00047-2

[8] Cheng, Q., Rao, P.V. and Zigler, J.S. (2001) Effect of Perillic Acid, a Putative Isoprenylation Inhibitor, on the Cultured Rat Lens. Experimental Eye Research, 73, 239-245.

[9] Dolder, S., Hofstetter, W., Wetterwald, A.C., Mühlbauer, R.C. and Felix, R. (2006) Effect of Monoterpenes on the Formation and Activation of Osteoclasts in Vitro. Journal of Bone and Mineral Research, 21, 647-655. https://doi.org/10.1359/jbmr.060111

[10] Ferri, N., Arnaboldi, L., Orlandi, A., Yokoyama, K., Gree, R., Granata, A., Hachem, A., Paoletti, R., Gelb, M.H. and Corsini, A. (2001) Effect of S(-) Perillic Acid on Protein Prenylation and Arterial Smooth Muscle Cell Proliferation. Biochemical Pharmacology, 62, 1637-1645.

[11] Inouye, S., Takizawa, T. and Yamaguchi, H. (2001) Antibacterial Activity of Essential Oils and Their Major Constituents against Respiratory Tract Pathogens by Gaseous Contact. Journal of Antimicrobial Chemotherapy, 47, 565-573. https://doi.org/10.1093/jac/47.5.565

[12] Karp, F., Mihaliak, C.A., Harris, J.L. and Croteau, R. (1990) Monoterpene Biosynthesis: Specificity of the Hydroxylations of (-)-Limonene by Enzyme Preparations from Peppermint (Mentha piperita), Spearmint (Mentha spicata), and Perilla (Perilla frutescens) Leaves. Archives of Biochemistry and Biophysics, 276, 219-226.

[13] Gonçalves, J.A., Bueno, A.C. and Gusevskaya, E.V. (2006) Palladium-Catalyzed Oxidation of Monoterpenes: Highly Selective Syntheses of Allylic Ethers from Limonene. Journal of Molecular Catalysis A: Chemical, 252, 5-11.

[14] Kholdeeva, O.A. (2014) Recent Developments in Liquid-Phase Selective Oxidation Using Environmentally Benign Oxidants and Mesoporous Metal Silicates. Catalysis Science \& Technology, 4, 1869-1889. https://doi.org/10.1039/c4cy00087k

[15] Marmulla, R. and Harder, J. (2014) Microbial Monoterpene Transformations-A Review. Frontiers in Microbiology, 5, 346. https://doi.org/10.3389/fmicb.2014.00346 
[16] Duetz, W.A., Bouwmeester, H., Van Beilen, J.B. and Witholt, B. (2003) Biotransformation of Limonene by Bacteria, Fungi, Yeasts, and Plants. Applied Microbiology and Biotechnology, 61, 269-277. https://doi.org/10.1007/s00253-003-1221-y

[17] Speelmans, G., Bijlsma, A. and Eggink, G. (1998) Limonene Bioconversion to High Concentrations of a Single and Stable Product, Perillic Acid, by a Solvent-Resistant Pseudomonas putida Strain. Applied Microbiology and Biotechnology, 50, 538-544. https://doi.org/10.1007/s002530051331

[18] Mirata, M.A., Heerd, D. and Schrader, J. (2009) Integrated Bioprocess for the Oxidation of Limonene to Perillic Acid with Pseudomonas putida DSM 12264. Process Biochemistry, 44, 764-771.

[19] Willrodt, C., Halan, B., Karthaus, L., Rehdorf, J., Julsing, M.K., Buehler, K. and Schmid, A. (2017) Continuous Multistep Synthesis of Perillic Acid from Limonene by Catalytic Biofilms under Segmented Flow. Biotechnology and Bioengineering, 114, 281-290. https://doi.org/10.1002/bit.26071

[20] Van Rensburg, E., Molekeli, N., Van der Walt, J.P., Botes, P.J. and Van Dyk, M.S. (1997) Biotransformation of (+)-Limonene and (-)-Piperitone by Yeasts and YeastLike Fungi. Biotechnology Letters, 19, 779-782.

https://doi.org/10.1023/A:1018344411069

[21] Ferrara, M.A., Almeida, D.S., Siani, A.C., Lucchetti, L., Lacerda, P.S.B., Freitas, A., Tappin, M.R.R. and Bon, E.P.S. (2013) Bioconversion of R-(+)-Limonene to Perillic Acid by the Yeast Yarrowia lipolytica. Brazilian Journal of Microbiology, 44, 1075 1080. https://doi.org/10.1590/S1517-83822014005000008

[22] Fickers, P., Benetti, P.H., Wache, Y., Marty, A., Mauersberger, S., Smit, M.S. and Nicaud, J.M. (2005) Hydrophobic Substrate Utilisation by the Yeast Yarrowia lipolytica, and Its Potential Applications. FEMS Yeast Research, 5, 527-543. https://doi.org/10.1016/j.femsyr.2004.09.004

[23] Gellissen, G., Kunze, G., Gaillardin, C., Cregg, J.M., Berardi, E., Veenhuis, M. and Van der Klei, I. (2005) New Yeast Expression Platforms Based on Methylotrophic Hansenula polymorpha and Pichia pastoris and on Dimorphic Arxula adeninivorans and Yarrowia lipolytica-A Comparison. FEMS Yeast Research, 5, 1079-1096. https://doi.org/10.1016/j.femsyr.2005.06.004

[24] Rodrigues, M.I. and Iemma, A.F. (2005) Planejamento de Experimentos e Otimização de Processos. Uma estratégia sequencial de planejamento, Ed. Casa do Pão, Campinas.

[25] Negro, V., Mancini, G., Ruggeri, B. and Fino, D. (2016) Citrus Waste as Feedstock for Bio-Based Products Recovery: Review on Limonene Case Study and Energy Valorization. Bioresource Technology, 214, 806-815.

[26] Krühne, U., Heintz, S., Ringborg, R., Rosinha, I.P., Tufvesson, P., Gernaey, K.V. and Woodley, J.M. (2014) Biocatalytic Process Development Using Microfluidic Miniaturized Systems. Green Processing and Synthesis, 3, 23-31. https://doi.org/10.1515/gps-2013-0089

[27] FAOSTAT. Food and Agriculture Organization of the United Nations Home Page. http://faostat3.fao.org/browse/Q/QC/E

[28] Ferreira-Leitão, V., Gottschalk, L.M.F., Ferrara, M.A., Nepomuceno, A.L., Molinari, H.B.C. and Bon, E.P.S. (2010) Biomass Residues in Brazil: Availability and Potential Uses. Waste Biomass Valorization, 1, 65-76. https://doi.org/10.1007/s12649-010-9008-8 
Submit or recommend next manuscript to SCIRP and we will provide best service for you:

Accepting pre-submission inquiries through Email, Facebook, LinkedIn, Twitter, etc. A wide selection of journals (inclusive of 9 subjects, more than 200 journals)

Providing 24-hour high-quality service

User-friendly online submission system

Fair and swift peer-review system

Efficient typesetting and proofreading procedure

Display of the result of downloads and visits, as well as the number of cited articles Maximum dissemination of your research work

Submit your manuscript at: http://papersubmission.scirp.org/

Or contact gsc@scirp.org 